Stanisława Krasucka SM

\title{
Święta Katarzyna Labouré wzorem realizacji powołania wincentyńskiego
}

(60) https://doi.org/10.15633/9788374389778.04

\section{Czym jest powołanie chrześcijańskie?}

$\mathrm{Na}$ początku zastanówmy się, czym jest powołanie chrześcijańskie. W chrześcijaństwie przez powołanie rozumie się najczęściej wezwanie człowieka przez Boga do określonego sposobu życia. Papież Franciszek w adhortacji apostolskiej Gaudete et exsultate. O powołaniu do świętości $w$ świecie współczesnym pomaga nam to zagadnienie jeszcze lepiej zrozumieć:

Poprzez tę adhortację chciałbym przede wszystkim przypomnieć o powołaniu do świętości, które Pan kieruje do każdego z nas, o tym wezwaniu, które kieruje też do ciebie: „Bądźcie świętymi, bo Ja jestem święty” (Kpł 11, 44; $1 \mathrm{P}$ 1, 16). Sobór Watykański II powiedział to dobitnie: „Wszyscy wierni, wyposażeni w tyle tak wielkich środków zbawienia, we wszystkich sytuacjach życiowych i w każdym stanie powołani są przez Pana, każdy na właściwej sobie drodze, do doskonałej świętości, jak sam Ojciec jest doskonały"

1 Franciszek, Gaudete et exsultate, 10. 
Zwróćmy uwagę na to, co powiedział Sobór: „Każdy na właściwej sobie drodze", kładąc w ten sposób akcent na niepowtarzalność każdego człowieka i na osobistą odpowiedzialność za realizację powołania. Papież Franciszek podkreśla też, że:

Istnieją świadectwa przydatne, by nas pobudzić i motywować. [...] Liczy się to, aby każdy wierny rozpoznał swoją drogę i wydobył z siebie to, co ma najlepszego, to, co najbardziej osobistego Bóg w nim umieścił (por. 1 Kor 12, 7) [...]. Wszyscy jesteśmy powołani, aby być świadkami, ale istnieje wiele egzystencjalnych form świadectwa².

Wielu ludziom udało się pięknie wypełnić chrześcijańskie powołanie do świętości. Na różne sposoby kroczyli ku niebu w pielgrzymce wiary, wyposażeni w osobiste charyzmaty lub włączeni we wspólnoty, żyjące konkretną duchowością własnych założycieli, które zawsze są bogactwem Kościoła.

Dziś pragniemy przypatrzeć się Katarzynie Labouré, Siostrze Miłosierdzia, która zrealizowała swoje chrześcijańskie powołanie do świętości na drodze realizacji powołania wincentyńskiego.

\section{Czym jest powołanie wincentyńskie?}

Chrześcijanin nie może myśleć o swojej misji na ziemi, nie pojmując jej jako drogi świętości, ponieważ „wolą Bożą jest nasze uświęcenie” - tak nam przypomina św. Paweł w 1 Tes 4, 3. Każdy święty jest misją, jest planem Ojca, by odzwierciedlać, ucieleśniać w danym momencie dziejów pewien aspekt Ewangelii ${ }^{3}$.

Zatem czym jest, jak opisać i zrozumieć powołanie, które nazywamy wincentyńskim? Powołanie wincentyńskie to sposób kroczenia za Chrystusem za przykładem św. Wincentego a Paulo (1581-1660), który spotkał Jezusa i odkrył Go w Ewangelii oraz w spotkaniu z Ubogim, a dokładnie najuboższym na tym świecie jako „Wielbiciel Ojca, Sługa Jego planu Mi-

\footnotetext{
2 Tamże, 11.

3 Por. tamże, 19.
} 
łości i Głosiciel Ewangelii Ubogim”“4 To jest właśnie ten aspekt Ewangelii, który odzwierciedlił w swoim życiu św. Wincenty a Paulo, a powołanie wincentyńskie najlepiej można opisać jego słowami:

Trzeba czynić to, co Syn Boży czynił na ziemi. A cóż On przede wszystkim czynił? Najpierw poddał w posłuszeństwie swoją wolę Maryi i św. Józefowi, a potem nieustannie pracował dla dobra bliźniego: odwiedzając i uzdrawiając chorych, nauczając nieumiejętnych celem zapewnienia im Zbawienia ${ }^{5}$.

Wincenty a Paulo i jego wierna współpracownica Ludwika de Marillac (1591-1660) zostali obdarzeni charyzmatem, czyli szczególnym darem Ducha Świętego ofiarowanym dla dobra Kościoła. Ich duchem od ponad czterech stuleci żyją miliony ludzi, których nazywamy Rodziną Wincentyńską. Charyzmat ten jest wciąż aktualny, a nawet paląco aktualny, jak to określił św. Jan Paweł II, zwracając się do Sióstr Miłosierdzia:

Charyzmat Księdza Wincentego jest paląco aktualny i do was, wraz z całą rodziną duchową, należy ożywianie go tam, gdzie jesteście posłane. Siostry Miłosierdzia, miejcie odwagę waszych Założycieli, by coraz bardziej uobecniać Kościół w świecie Ubogich i to w taki sposób, by Ubodzy czuli się rzeczywiście w Kościele jak u siebie! Bądźcie otwarte w waszych Prowincjach i w waszych Domach na bogactwo ludzi, którym służycie, aby w nich odkrywać dary Boga! Wtedy, z łaską Pana, będziecie mogły stać się czytelnymi znakami miłości wobec Ubogich ${ }^{6}$.

Taka jest właśnie duchowość wincentyńska, a jej sercem pozostaje tajemnica Wcielenia: Jezus przychodzący na ziemię, by ukazać miłujące Oblicze Boga Ojca, który kocha ten świat. Tak, Pan Bóg kocha ten świat, a Jego Miłość ma na imię miłosierdzie, które okazuje „z pokolenia na pokolenie", jak to wyśpiewała Maryja w swoim Magnificat (Łk 46, 50).

4 Por. Konstytucje i Statuty Sióstr Miłosierdzia, 8.

5 Saint Vincent de Paul, Correspondances, entretiens, documents, t. 9, Paris 1920-1925, s. 15.

6 Jan Paweł II, List do Przełożonej Generalnej Sióstr Miłosierdzia z okazji Konwentu Generalnego, 2 maja 1997 roku. 
Oblicze miłosiernego Boga ukazało się w sposób szczególny w siedemnastowiecznej Francji poprzez fascynujący szlak duchowy Wincentego ${ }^{7}$, Ludwiki i wielu innych, którzy zostali pociągnięci ich przykładem. Św. Wincenty a Paulo uważny na to, by nie wyprzedzać zamiarów Opatrzności Bożej i uległy natchnieniom Ducha Świętego, odkrył nędzę materialną i duchową swoich czasów i poświęcił życie służbie ubogim, których nazywał „Panami i Mistrzami”. W tym celu założył Bractwa Miłosierdzia (1617), Zgromadzenie Misji (1625) i Siostry Miłosierdzia (1633). Opatrznościowo spotkał Ludwikę de Marillac, która podjęła z nim ścisłą współpracę w dobroczynnej działalności ${ }^{8}$. Należy tu wspomnieć, że jednym ze szczególnych rysów tej duchowości jest miłość i zaufanie do Dziewicy Maryi, jaką mieli ci święci ludzie. Jej opiece i wstawiennictwu zawierzali powstające dzieła miłosierdzia.

\section{Siostra Katarzyna Labouré - duchowa córka św. Wincentego a Paulo i św. Ludwiki de Marillac}

Na niezwykłą drogę podążania za Chrystusem na wzór św. Wincentego a Paulo dwa wieki później, bo w XIX wieku, wkroczyła również Katarzyna Labouré, prosta dziewczyna $z$ burgundzkiej wioski. Wpisała się ona w tę duchową sztafetę pokoleń. Najpierw do dwudziestego czwartego roku życia realizowała swoje powołanie chrześcijańskie. Miała szczęśliwy dom, w którym nabierała sił, równowagi i czuła się kochana. Wychowana w rodzinie katolickiej, nauczyła się rozmawiać z Bogiem, być uważną na Jego obecność. Rodzice wpoili jej solidne wartości: szacunek dla innych, prawość, umiejętność dzielenia się i umiłowanie sumiennej pracy. Mama nauczyła Katarzynę wielkiej miłości do Matki Bożej, której figura znajdowała się w ich rodzinnym domu, a także u wejścia do kościółka w Fainlès-Moutiers. Piękny obraz Maryi wisiał też na ścianie w kościele obok kaplicy rodziny Labouré. Wiemy, że Katarzyna, gdy miała dziewięć lat, po śmierci mamy, w szczególny sposób przytuliła się do Matki Bożej.

7 Por. Jan Paweł II, List apostolski z okazji 4oo-lecia urodzin św. Wincentego a Paulo, 12 maja 1981 roku.

8 Por. Konstytucje i Statuty Sióstr Miłosierdzia, 17. 
Katarzyna ukochała Eucharystię, zwłaszcza od dnia Pierwszej Komunii świętej. Ciężka praca nie przeszkadzała jej w częstym nawiedzaniu Jezusa Eucharystycznego. Była skupiona i jakby zasłuchana w świat nadprzyrodzony. Rozumiała wartość postów i umartwienia, zwłaszcza w piątki i soboty. Pan Bóg stopniowo, poprzez kolejne wydarzenia jej życia przygotowywał ją do wkroczenia na drogę realizacji powołania wincentyńskiego.

W wieku osiemnastu lat miała bardzo przedziwny i wymowny sen, który niejako zwiastował pragnienie Boga w stosunku do niej, a którego znaczenie zrozumiała dopiero później:

Byłam w kościele w Fain. Modliłam się. Nagle starszy kapłan podszedł do ołtarza i zaczął odprawiać Mszę Świętą. Wpatrywał się we mnie. Pod koniec Mszy Świętej dał mi znak, bym się zbliżyła i powiedział: „Kiedyś będziesz szczęśliwa, gdy do mnie przyjdziesz. Bóg ma wobec ciebie plany".

Co miałoby to znaczyć? Katarzyna nie rozumie tego jeszcze. Nadal $\mathrm{z}$ prostotą kontynuuje pracę w gospodarstwie. Wiemy, że w przyszłości odkryje, kim był ów kapłan. To św. Wincenty a Paulo, poprzez którego Pan woła ją, powołuje, daje znak, który tylko ona sama może właściwie odczytać: by szła ku Bogu drogą miłosiernej miłości, realizując w życiu powołanie wincentyńskie.

I rzeczywiście przyszła do niego 21 kwietnia 1830 roku, wstępując do Zgromadzenia Sióstr Miłosierdzia w Paryżu. Miała wówczas dwadzieścia cztery lata. Kwiecień tego roku naznaczony był szczególną obecnością św. Wincentego: to miesiąc jego urodzin i przeniesienia jego relikwii z katedry Notre-Dame do kościoła przy ul. de Sèvres w Paryżu, gdzie znajduje się Dom Macierzysty Księży Misjonarzy. Widzimy, że św. Wincenty w tym tak bardzo ważnym dla niej momencie był szczególnie blisko i można rzec - przygotował Katarzynie wspaniałe przyjęcie. Niejako sam czekał na nią. Wiemy, że brała udział w procesji przeniesienia relikwii Założyciela. Miała również wizje jego serca. To nie był przypadek i Katarzyna na pewno to rozumiała, ponieważ była wrażliwa na znaki działania Boga w jej życiu. Zapewne Katarzyna przypomniała sobie wtedy i bardziej pojęła znacze- 
nie snu, który kiedyś miała: Opatrzność Boża kilka lat wcześniej, jeszcze w domu rodzinnym, przygotowała ją do tej chwili.

Patrząc po ludzku, Katarzyna nie uczyniła nic nadzwyczajnego. Robiła to samo, co tysiące Sióstr Miłosierdzia: pokornie służyła ubogim. Jej świętość na drodze powołania wincentyńskiego realizowała się w codzienności: przez spotkania z ludźmi, przez dzielenie ich smutków, radości i nadziei, przez podejmowanie wciąż tej samej pracy i okazywanie dobra wszystkim, a zwłaszcza cierpiącym. Używając tu wyrażenia Franciszka: była „świętą z sąsiedztwa" ${ }^{10}$. Miłość pobudzała ją do poszukiwania nowych środków, by wraz z ubogimi zaradzać potrzebom każdego z nich. Starała się o ich promocję. Odznaczała się dwiema postawami: dobrocią i zdecydowaniem ${ }^{11}$.

René Laurentin, znany teolog i biograf Katarzyny, powiedział, że jest ona świadkiem nowego typu świętości, którą Duch Święty wzbudził też na dzisiejsze czasy, świętości pozbawionej ludzkiej chwały i triumfalizmu. Katarzyna potrafiła żyć charyzmatami na co dzień, a najważniejsze było dla niej służenie ubogim.

Nigdy nie zdołamy odkryć całej pełni bogactwa, jakie kryło się w sercu i życiu Katarzyny. Była zaszczycona objawieniami Maryi, ale pozostała cichą i zwyczajną szarytką. Jedną z najwyrazistszych cech jej życia było to, że żyła świętością na co dzień. Zwykłą codzienność, dzięki miłości, przeżywała niezwykle. Wcielała w życie to, czym żyli Wincenty i Ludwika, a co papież Franciszek nazywa dziś „wielką regułą postępowania”, która opisana jest przez św. Mateusza:

W rozdziale 25 Ewangelii wg św. Mateusza (ww. 31-46), Jezus [...] rozważa jedno z błogosławieństw - to, które ogłasza błogosławionymi miłosiernych. Jeśli szukamy tej świętości, która podoba się Bogu, to w tym tekście możemy znaleźć regułę postępowania, na podstawie której będziemy sądzeni: „Byłem głodny, a daliście Mi jeść; byłem spragniony, a daliście Mi pić; byłem przybyszem, a przyjęliście Mnie; byłem nagi, a przyodzialiście

10 „Lubię dostrzegać świętość w cierpliwym ludzie Bożym: w rodzicach, którzy z wielką miłością pomagają dorastać swoim dzieciom, w mężczyznach i kobietach pracujących, by zarobić na chleb, w osobach chorych, w starszych zakonnicach, które nadal się uśmiechają. W tej wytrwałości, aby iść naprzód, dzień po dniu, widzę świętość Kościoła walczącego. Jest to często «świętość z sąsiedztwa", świętość osób, które żyją blisko nas i są odblaskiem obecności Boga, albo, by użyć innego wyrażenia, są «klasą średnią świętości»". Franciszek, Gaudete et exsultate, 7.

11 Por. A. Prévost, Catherine Labouré, dz. cyt. s. 12-13. 
Mnie; byłem chory, a odwiedziliście Mnie; byłem w więzieniu, a przyszliście do Mnie" $(25,35-36)^{12}$.

Katarzyna była wierną uczennicą Świętych Założycieli. Znała i na pewno często rozważała ich rady, wskazówki, nauczanie i przypominała sobie słowa św. Ludwiki: „Mamy wielkie szczęście być córkami Kościoła Świętego. Czyż to nie zobowiązuje nas do wielkiej doskonałości?”"13. Tę doskonałość Katarzyna osiągała właśnie na drodze realizacji powołania wincentyńskiego.

\section{Szczególne cechy powołania wincentyńskiego realizowanego przez Katarzynę Labouré}

Duchowość wincentyńska jest na wskroś ewangeliczna, bo jej regułą jest Jezus Chrystus. 9 lutego 1653 roku, podczas konferencji wygłoszonej Siostrom Miłosierdzia na temat ducha Zgromadzenia, Wincenty powiedział:

Duch waszego Zgromadzenia polega na trzech rzeczach: kochać Pana Naszego i służyć Mu w duchu pokory i prostoty. Dopóki miłość, pokora i prostota będą wśród was, będzie można powiedzieć: Zgromadzenie Miłosierdzia jeszcze żyje ${ }^{14}$.

Realizacja powołania wincentyńskiego zakłada zatem życie trzema głównymi cnotami: pokorą, prostotą i miłością. Życie s. Katarzyny Labouré, nazywanej „Świętą milczenia i życia ukrytego”, mającej serce przy Bogu, a ręce przy pracy, było pokorne, proste i pełne miłości.

\section{Pokora. Święta życia ukrytego}

We wspomnianej wcześniej konferencji, Wincenty powtarza: „Bóg chce, aby Siostry Miłosierdzia przykładały się w sposób szczególny do praktyko-

\footnotetext{
12 Franciszek, Gaudete et exsultate, 95.

13 Sainte Louise de Marillac, Écrits Spirituels, Tours 1983, L. 179, s. 202.

14 Saint Vincent de Paul, Correspondances, dz. cyt., s. 594-595.
} 
wania pokory, prostoty i miłości" ${ }^{15}$. Katarzyna kochała Pana Boga i swoje powołanie. Kochała też bardzo św. Wincentego a Paulo. Była wciąż uważna na to, by nigdy nie minąć się z zamiarami Boga wobec niej. Pragnęła we wszystkim pełnić wolę Bożą, co było kluczowe dla św. Wincentego. Dlatego brała sobie do serca wskazania Założyciela, które poznała w czasie formacji początkowej i pogłębiała w ciągu całego życia. Była bardzo konsekwentna i wierna w realizacji wymagań powołania, jakim została obdarzona.

Jej relacje z ludźmi nacechowane były wielką pokorą. Charakterystyczne dla niej opanowanie i zdolność słuchania wyrażały wielki i głęboki szacunek dla bliźniego. Katarzyna starała się być służebnicą. Dzięki modlitwie odkryła pokorę Jezusa i Maryi i właśnie od Nich uczyła się tej cnoty. Na pewno nie było jej łatwo, ponieważ miała mocny charakter, co więcej od wczesnej młodości zarządzała, będąc gospodynią. U początku drogi w Zgromadzeniu, w liście adresowanym do Katarzyny, pięknie pisze o tym jej siostra Maria Ludwika (również szarytka):

Mam nadzieję, że w drodze z Chatillon do Paryża pozbyłaś się własnej woli. [...]. Na pewno wola naszych przełożonych jest lepsza od naszej. Wyobraź sobie, że nie będąc już gospodynią na fermie, nie umiesz nic robić [...]. Moja kochana, w seminarium trzeba gromadzić zapasy wszystkich cnót [...], a zwłaszcza pokory ${ }^{16}$.

Katarzyna musiała walczyć przeciwko chęci dominacji. Uczyła się autentycznego życia pokorą jako cnotą miłą Bogu, która napełnia duszę pokojem i równowagą oraz prowadzi na wyżyny świętości. Pokory nie mierzy się podejmowaniem najniższych i najskromniejszych posług. Istotą pokory jest to, by nie polegać na własnych tylko siłach i możliwościach, ale by nade wszystko liczyć się z Bogiem, bo „wszystko możemy tylko w Nim, który nas umacnia”, jak to stwierdził dobitnie św. Paweł (por. Flp 4, 13). Pokora jest ściśle związana z miłością i pozwala Bogu działać.

Katarzyna była świadoma tego, że prawdziwym uczniem Jezusa może być ten, kto idzie za Nim każdego dnia, nie od czasu do czasu, według własnego kaprysu. A do tego jeszcze ma brać swój krzyż i angażować się konkretnie w rzeczywistość, w jakiej przychodzi mu żyć. Rzeczywistoś-

15 Tamże, s. 596.

16 R. Laurentin, Prawdziwe życie Katarzyny Labouré, Kraków 1995, s. 71. 
cią życia Katarzyny była wspólnota sióstr, relacje ze spotykanymi ludźmi, a zwłaszcza z ubogimi. Znakami jej pokory były również: serdeczność, pogoda ducha, a także szacunek do każdej siostry i do każdego człowieka. Tam, gdzie pracowała: w przytułku dla osób starszych i chorych, miała dużo okazji do praktykowania cnót, zwłaszcza tych zalecanych przez św. Wincentego. Miała tendencje do tego, by reagować żywo w sprawach, które mocno leżały jej na sercu, ale dzięki pokorze uczyła się panować nad swoją żywiołową naturą. Umiała wycofać się z własną oceną, gdy widziała, że mogłaby ona zaszkodzić jedności lub w jakikolwiek sposób poniżyć bliźniego. Nie wysuwała się na pierwsze miejsce i nie opowiadała o swoich dokonaniach, gdyż nigdy nie chciała okazać komukolwiek wyższości czy stawiać na swoim, czy też forsować własnego zdania. Pokora czyniła ją wolną. Pokora pozwalała jej słuchać bliźnich.

Katarzyna posiadała również dużą intuicję i empatię, a także pewną zdolność odkrywania tego, co działo się w drugim człowieku. Osobista praca nad sobą, branie na serio Ewangelii i duchowości wincentyńskiej sprawiały, że w jej życiu triumfowała pokora. Katarzyna zdawała sobie sprawę, że pokora jest fundamentem jedności i balsamem na sytuacji konfliktowe. Była pomysłowa w jej praktykowaniu. Po nieporozumieniach pierwsza nawiązywała rozmowę tak, jakby nic się nie wydarzyło. Umiała przechodzić ponad podziałami. Nie uciekała od innych, ale wychodziła im naprzeciw, szukając pretekstu do rozmowy. Tylko łaska Boża, z którą solidnie współpracowała, mogła skłonić „dumną Labouré” do uniżenia się i bycia przykładem łagodności i pokory. Serdeczność, poświęcanie czasu innym i słuchanie to znaki pokory tak bardzo ważne w budowaniu relacji braterskich i piękniejszego świata. Życie Katarzyny było odbiciem słów św. Ludwiki: „Żyć w pokorze, zawsze mając na względzie raczej potrzeby osób, z którymi mamy do czynienia, aniżeli nasze własne, a nawet i Zgromadzenia"17.

Spokojne przyjmowanie przeciwności i trudów życia, czuwanie nad sobą, rozeznawanie przejawów pychy i chęci dominacji oraz akceptowanie własnych ograniczeń, niezniechęcanie się i wierne szukanie woli Bożej sprawiło, że Katarzyna coraz bardziej upodabniała się do Chrystusa i w ten sposób dążyła do pełni człowieczeństwa na wzór Wcielonego Słowa Boże-

17 Sainte Louise de Marillac, Écrits Spirituels, dz. cyt., L. 183, s. 207. 
go, Jezusa Chrystusa, który uniżył samego siebie, przyjąwszy postać Sługi. To w Nim ukryła całe swoje życie.

\section{Prostota. Serce przy Bogu}

Prostota była cnotą bardzo cenioną przez Wincentego a Paulo. Nazywał ją swoją Ewangelią: „Bóg daje mi tak wielką cześć dla prostoty, że nazywam ją moją Ewangelią. Mam szczególne nabożeństwo i pociechę, kiedy mówię o rzeczach takich, jakimi są"18.

Prostota wiedzie prosto do Boga i skłania do poszukiwania, umiłowania i obrony prawdy w sytuacjach niesprawiedliwości oraz do działania w duchu przejrzystości, autentyczności, zgodności słów z życiem. Prostota wiodła Katarzynę prosto do Boga. Sprawiała, że była przejrzysta, autentyczna i postępowała zgodnie z tym, co mówiła. Jej intencje były czyste. Pragnęła podobać się tylko Bogu. Niczego nie robiła na pokaz. Miała serce przy Bogu i potrafiła wszystko widzieć w Nim. Bóg był dla niej naprawdę Obecnością. Kontemplowała Go nie tylko na modlitwie, ale także w codzienności życia, w tym co ludzkie. Czystość i prostota serca dawały jej przystęp do tej Obecności. Tak bardzo przypominają się tu słowa Jezusa: „Błogosławieni czystego serca, albowiem oni Boga oglądać będą” (por. Mt 5, 8), a także: „Wysławiam Cię, Ojcze, Panie nieba i ziemi, że zakryłeś te rzeczy przed mądrymi i roztropnymi, a objawiłeś je prostaczkom" (Mt 11, 25).

Patrząc na życie św. Katarzyny Labouré, można powiedzieć, że dostrzegała „Boga we wszystkim”, widziała „wszystko w Bogu” i czyniła „wszystko dla Boga". Takie postrzeganie świata prowadziło ją do kontemplacji i do zjednoczenia serca z Bogiem.

W duchu wiary Katarzyna umiała dostrzec Boga w wydarzeniach pomyślnych i nieszczęśliwych. Nawet w trudnych doświadczeniach mówiła: „Dobry Bóg jest obecny we wszystkich wydarzeniach”. Patrzyła na ludzi pozytywnie. Starała się ich rozumieć, a nie sądzić. Nie zatrzymywała się na powierzchni wydarzeń, bo to prowadzi najczęściej do ponurej wizji rzeczywistości. Patrzyła dalej niż wydarzenia. Patrzyła z ufnością na trudne sytuacje. Mówiła czasem: „Pozwólcie działać Bogu, On lepiej wie, czego nam potrzeba".

18 Saint Vincent de Paul, Correspondances, dz. cyt., s. 606. 
W kapłanach widziała przedstawicieli samego Boga, a w przełożonych pośredników w rozpoznawaniu woli Bożej, nawet jeśli wydawała się ona pełna tajemnic. Dostrzegała Boga w swoich współsiostrach w wierze. Patrzyła na nie spojrzeniem prostym i pełnym miłości. W sposób szczególny dostrzegała Boga w ubogich. Wiedziała, że w każdym z nich jest sam Chrystus: w umierającym, w kalekim, w sierocie... Katarzyna potrafiła uczyć się od innych i umiała dostrzegać Boga nawet we własnych niedoskonałościach. „Bardzo się cieszę, że poznano prawdę” - tak mówiła, gdy wykazywano, że nie miała racji, albo gdy mówiono o jej słabościach. Oddała serce Bogu, dlatego godziła się z własnymi ograniczeniami i rosła w wewnętrznej wolności.

\section{Miłość. Ręce przy pracy}

Miłość, do jakiej została powołana Katarzyna, to miłość samego Jezusa Chrystusa, która uzdalniała ją do kochania Boga oraz pomagała w budowaniu komunii z innymi, a nade wszystko przynaglała ją do służenia ubogim i do pomagania każdemu w realizowaniu powołania dziecka Bożego:

Jesteście przeznaczone na to, byście przedstawiały dobroć Boga wobec Ubogich... trzeba się także obchodzić z nimi tak jak ta sama dobroć was naucza, to znaczy ze słodyczą, współczuciem i miłością; są to bowiem wasi mistrzowie ${ }^{19}$.

Św. Katarzynie nie wystarczało, że sama kochała Pana Boga. Naturalnym skutkiem tej miłości było to, że kochała też całym sercem ludzi i pragnęła, by poznali i ukochali miłosiernego Boga. Służba nie była dla niej tylko czymś do wykonania, ale raczej Kimś, kogo trzeba kochać. Dzieląc się głębią swego serca z ubogimi, pozwalała im zakosztować Miłości Bożej, która przepełniała jej serce ${ }^{20}$.

Swoją miłość do ubogich przeżywała, podejmując pokornie codzienne niskie posługi. Radośnie, czasem z humorem i pogodą ducha, wykonywała liczne zajęcia, wybierając zwłaszcza te, które były niewdzięczne, po-

19 Tamże, s. 332. Wincenty dodał też: „z serdecznością, poszanowaniem i pobożnością”. Por. tamże, s. 331.

20 Por. A. Prévost, Catherine Labouré, dz. cyt., s. 16. 
gardzane i wymagały ciężkiej pracy. Z humorem - to bardzo ważne. We wspomnianej już adhortacji, Franciszek również mówi o radości i poczuciu humoru:

Święty jest zdolny do życia pełnego radości i poczucia humoru. Nie tracąc realizmu, oświeca innych pozytywnym i pełnym nadziei duchem. Bycie chrześcijanami jest „radością w Duchu Świętym” (Rz 14, 17), gdyż miłość miłosierdzia koniecznie podąża za radością... ${ }^{21}$.

A spośród tak wielu świętych, papież wyróżnia trzech i jest wśród nich św. Wincenty a Paulo:

Zazwyczaj radości chrześcijańskiej towarzyszy poczucie humoru, tak widoczne, na przykład u św. Tomasza Morusa, u św. Wincentego a Paulo, czy też św. Filipa Nereusza. Zły humor nie jest oznaką świętości: „usuń przygnębienie ze swego serca!" (Koh 11, 10). Tak wiele otrzymujemy od Pana „do używania” (1Tm 6, 17), że niekiedy nasz smutek związany jest $\mathrm{z}$ niewdzięcznością, z byciem tak bardzo zamkniętym w sobie, że jest się niezdolnym do przyjęcia Bożych darów ${ }^{22}$.

Dbając o pogodę ducha, Katarzyna pracowała bez pośpiechu i jednocześnie bez wytchnienia. Nadmiar pracy i trosk potrafiła zrównoważyć modlitwą. Tu właśnie odnaleźć można istotę jej sekretu: serce przy Bogu i ręce przy pracy. Pomimo codziennych obowiązków była wspomnianą „świętą z sąsiedztwa”. Nie ograniczała się do posługi starszym ludziom w przytułku, ale była też uważna na potrzeby i nędzę rodzin z dzielnicy i sąsiadów. Znała wyczerpującą pracę robotników, ich trudne warunki mieszkaniowe, nędzę duchową i niepokój rodzin wyrzuconych na bruk ${ }^{23}$. Chociaż nie dysponowała odpowiednimi środkami, zawsze starała się szukać rozwiązań, by zaspokoić ich potrzeby materialne i duchowe, bo takie jest powołanie wincentyńskie, które realizowała swoim życiem. Dzięki wrodzonemu taktowi i poczuciu sprawiedliwości Katarzyna odważnie konfrontowała się z trudnymi sytuacjami i niosła pomoc, dbając, by ludzie stawali na nogi

\footnotetext{
21 Franciszek, Gaudete et exsultate, 122.

22 Tamże, 126.

23 Por. R. Laurentin, Prawdziwe życie, dz.cyt., s. 11.
} 
i brali życie we własne ręce. Pomagała każdemu stawać się odpowiedzialnym, odzyskiwać poczucie własnej godności i szanować godność innych dla wspólnego dobra.

Aż do ostatnich miesięcy swojego życia podejmowała ciężką pracę, krzątając się przy chorych i po korytarzach, które zawsze były posprzątane i czyste tak, że lśniły jak korytarze w pałacu, bo przecież ubodzy byli jej Panami i Mistrzami. Jeszcze na miesiąc przed śmiercią, pomimo bolących kolan, szorowała krzesła-sedesy pensjonariuszy, klęcząc przy studni na podwórku.

Katarzyna dbała o szczegóły. To takie ważne i dziś. Franciszek przypomina nam postawę samego Jezusa, dla którego ważne były małe rzeczy:

- Pamiętajmy, jak Jezus zachęcał swoich uczniów, by zwracali uwagę na szczegóły.

- Drobny szczegół, że na uczcie weselnej zaczęło brakować wina.

- Drobny szczegół, że zabrakło jednej owcy.

- Drobny szczegół, że wdowa złożyła w ofierze dwa pieniążki.

- Drobny szczegół posiadania zapasu oleju do lamp na wypadek, gdyby oblubieniec się opóźniał.

- Drobny szczegół, aby zapytać uczniów, ile mają chlebów.

- Drobny szczegół przygotowania żarzących się węgli, a na nich ryb, gdy czekał na uczniów o świcie ${ }^{24}$.

Katarzynie udało się zadbać o te drobne szczegóły spokojnie i bez hałasu.

Katarzyna jest wzorem realizacji powołania wincentyńskiego. Kontemplowała i spotykała Chrystusa w sercu i życiu ubogich, tam, gdzie nieustannie działa Jego łaska. Główną troską świętej było służenie im co do ciała i co do duszy, umożliwienie im poznania Boga, głoszenie Ewangelii słowem i czynem oraz uobecnianie Królestwa Bożego: sprawiedliwości, pokoju i radości w Duchu Świętym. Katarzyna jest świętą, która wygrała życie, idąc za Panem na wzór św. Wincentego a Paulo. Jej przykład jest dziś bardzo aktualny, a nawet paląco aktualny. Myślę, że poniższe słowa papieża Franciszka można odnieść konkretnie do jej życia:

24 Franciszek, Gaudete et exsultate, 144. 
Zatem bycie świętym nie oznacza oczu jaśniejących w domniemanej ekstazie. Św. Jan Paweł II powiedział, że „jeśli nasze działania rzeczywiście mają początek w kontemplacji Chrystusa, to powinniśmy umieć Go dostrzegać przede wszystkim w twarzach tych, z którymi On sam zechciał się utożsamić”. Słowa z Ewangelii Mateusza $(25,35-36)$ „nie są jedynie wezwaniem do miłosierdzia: zawierają one głęboki sens chrystologiczny, który ukazuje w pełnym blasku tajemnicę Chrystusa". W tym wezwaniu do rozpoznania Go w ubogich i cierpiących, objawia się samo serce Chrystusa, Jego uczucia i najgłębsze decyzje, do których każdy święty próbuje się dostosować ${ }^{25}$.

Papież Pius XII, w przemówieniu podczas kanonizacji Katarzyny, nazwał ją „świętą milczącą” i dodał, iż „została świętą nie z powodu objawień, lecz dlatego, że przez całe życie służyła Chrystusowi w ubogich, że w milczeniu i z pokorą każdego dnia spełniała wolę Bożą, że podejmowała współdziałanie z Bożą łaską" ${ }^{26}$. Słowa te dobrze opisują świętą siostrę Katarzynę Labouré, którą prosimy o wstawiennictwo za nami.

\section{Litania do św. Katarzyny Labouré}

Kyrie eleison, Chryste eleison, Kyrie eleison.

Chryste usłysz nas, Chryste wysłuchaj nas.

Ojcze z nieba Boże, zmiłuj się nad nami.

Synu Odkupicielu świata Boże, zmiłuj się nad nami.

Duchu Święty Boże, zmiłuj się nad nami.

Święta Trójco, Jedyny Boże, zmiłuj się nad nami.

Święta Maryjo, módl się za nami.

Święta Boża Rodzicielko,

Święta Maryjo Niepokalana,

Patronko Sióstr Miłosierdzia,

Święta Katarzyno Labouré,

Święta Katarzyno, wybranko Najświętszej Panny Maryi Niepokalanej,

Święta Katarzyno, wierna duchowna córko św. Wincentego a Paulo i św. Ludwiki,

25 Tamże, 96.

26 E. Crapez, Le Message du Cour de Marie à Sainte Catherine Labouré, Paris 1947, s. 222. 
Święta Katarzyno, wzorze posłuszeństwa i umartwienia, Święta Katarzyno, któraś swą niewinnością spodobała się Jezusowi i Najświętszej Dziewicy,

Święta Katarzyno, wielce rozmiłowana w Najświętszym Sercu Jezusa i Maryi, Święta Katarzyno, naśladowczyni Najświętszego Serca w cichości i pokorze, Święta Katarzyno, której Matka Najświętsza raczyła się objawić w chwale Niepokalanego Poczęcia,

Święta Katarzyno, apostołko Cudownego Medalika, przez który rozlały się potoki łask na wyschniętą ziemię,

Święta Katarzyno, pierwsza organizatorko wielkich zastępów Dzieci Maryi, Święta Katarzyno, patronko Stowarzyszenia Dzieci Maryi, Święta Katarzyno, kwiecie w ogrodzie Sióstr Miłosierdzia, Święta Katarzyno, rozmiłowana w pokornych zajęciach aż do śmierci, Święta Katarzyno, czysta gołębico przedziwnej prostoty, Święta Katarzyno, troskliwa opiekunko starców, Święta Katarzyno, miłosierna opiekunko ubogich i nieszczęśliwych, Święta Katarzyno, litościwa pocieszycielko chorych, Święty Katarzyno, obdarzona przez Ducha Świętego darem proroctwa, Święta Katarzyno, wesele i ozdobo Sióstr Miłosierdzia, Święta Katarzyno, cudami od Boga wsławiona, Święta Katarzyno, jasny promieniu niebios,

Abyśmy Najświętszą Maryję Pannę jako, najmilszą Matkę miłowali, uproś nam u Niepokalanej.

Abyśmy obowiązki swoje pokornie i sumiennie spełniali, Abyśmy, wszystkie przeciwności i cierpienia zbawiennie znosili, Abyśmy Boga i Matkę Najświętszą z Tobą na wieki chwalili, Baranku Boży, który gładzisz grzechy świata, przepuść nam, Panie. Baranku Boży, który gładzisz grzechy świata, wysłuchaj nas, Panie. Baranku Boży, który gładzisz grzechy świata, zmiłuj się nad nami.

K. Módl się za nami św. Katarzyno.

W. Abyśmy się stali godnymi obietnic Chrystusowych.

K. Módlmy się. 
Wysłuchaj nas, Boże, Zbawicielu nasz, abyśmy, jako się weselimy z wywyższenia świętej Katarzyny Labouré, Dziewicy Twojej, tak też żywili w sercach uczucia prawdziwej pobożności. Przez Chrystusa, Pana naszego.

W. Amen.

\section{Abstrakt}

Święta Katarzyna Labouré wzorem realizacji powołania wincentyńskiego

Artykuł omawia zagadnienie życia św. Katarzyny Labouré pod kątem realizacji powołania wincentyńskiego na wzór św. Wincentego a Paulo, który spotkał Jezusa i odkrył Go w Ewangelii oraz w spotkaniu z Ubogim, a dokładnie najuboższym na tym świecie. Świętość Katarzyny jest ukazana jako dostępna dla każdego, jako „świętość z sąsiedztwa”, jak ją nazywa papież Franciszek w Gaudete et exsultate. Jej wyróżnikami w życiu św. Katarzyny są: prostota, pokora i miłość.

Słowa kluczowe: Katarzyna Labouré, duchowość wincentyńska, świętość, cnoty

\section{Abstract}

Saint Catherine Labouré as a model for the realization of the vincentian vocation

The article discusses the question of the life of St. Catherine Labouré in terms of the realization of the Vincentian vocation following the example of St. Vincent de Paul, who encountered Jesus and discovered Him in the Gospel and in the encounter with the poor, specifically the poorest in this world. Catherine's holiness is portrayed as accessible to everyone, as a „neighborhood holiness”, as Pope Francis calls it in Gaudete et exsultate. Her qualities in St. Catherine's life are simplicity, humility, and charity. 
Keywords: St. Catherine Labouré, Vincentian spirituality, sanctity, virtues

\section{Bibliografia}

1. Crapez E., Le Message du Cour de Marie à Sainte Catherine Labouré, Paris 1947.

2. Franciszek, Adhortacja apostolska Gaudete et exsultate o powołaniu do świętości w świecie współczesnym, 19 marca 2018 roku.

3. Jan Paweł II, List Apostolski z okazji 40o-lecia urodzin Św. Wincentego a Paulo, 12 maja 1981 roku.

4. Jan Paweł II, List do Przełożonej Generalnej Sióstr Miłosierdzia z okazji Konwentu Generalnego, 2 maja 1997 roku.

5. Konstytucje i Statuty Sióstr Miłosierdzia.

6. Laurentin R., Prawdziwe życie Katarzyny Labouré, Kraków 1995.

7. Prévost A., Catherine Labouré. Messagère du Ciel, Paris 2005.

8. Sainte Louise de Marillac, Écrits Spirituels, Tours 1983.

9. Saint Vincent de Paul, Correspondances, entretiens, documents, t. 9, Paris $1920-1925$. 
Aniwersytet Papieski

ifl Jana Pawta II

(b) wrakowie 